\title{
Unveiling the consequences of your breach growth model choice
}

\author{
P. Peeters ${ }^{1,2, a}$, M. Heredia Gomez ${ }^{3}$, M. van Damme ${ }^{2}$, P.J. Visser ${ }^{2}$ \\ ${ }^{1}$ Flanders Hydraulics Research, Flemish Authorities, Antwerp, Belgium \\ ${ }^{2}$ Department of Hydraulic Engineering, Delft University of Technology, Delft, The Netherlands \\ ${ }^{3}$ Antea Group, Ghent, Belgium
}

\begin{abstract}
Within the frame work of the realisation of the 'Sigmaplan' for the river Schelde in Flanders (Belgium), a large-scale dike breaching experiment following overflow was held at Lillo (Antwerp) in 2012. The outcomes of the breach test serve to unveil the impact of a chosen breach growth model, to set application limits, to come up with guidelines for proper selection and usage of the model to be applied.
\end{abstract}

\begin{abstract}
Breach growth models are used to predict the breach dimensions and to estimate the flow through the breach. All assessed models pretty well succeed in this. However, starting from various premises and taking into account a (limited) set of different breaching mechanisms, the use of today's state-of-the-art breach growth models is not entirely trouble free
\end{abstract}

\section{Introduction}

Within the frame work of the realization of the 'Sigmaplan' for the river Schelde in Flanders (Belgium), large-scale dike breaching experiments following overflow are organised. The setup and outcomes of one of these field tests, the so-called "Lillo A" experiment, is described by [1]. In this study, 6 breach growth models are used to simulate the "Lillo A" breaching test. Following these simulations, results, limitations and pitfalls are discussed in this paper.

\section{Applied breach growth models}

The main use of breach models includes two tasks: predicting breach characteristics and estimating flow through the breach. For these purposes, in literature breaching models can be found ranging from simplified conceptually- to detailed physically-based. In this study, the choice of breach models was based on the availability of the code, experience and expertise with the model rather than covering the entire spectrum of breaching models.

\subsection{Breaching module in MIKE (DHI)}

Within Mike11 breach growth can be modelled using a Dambreak structure. The flow through the breach is obtained by considering a broad crested weir with changing crest level and length (i.e. breach width). A dimensionless (bed) shear stress, i.e. Shields' particle mobility parameter, is calculated requiring a grain size diameter $\left(\mathrm{d}_{50}\right)$ and a specific gravity $(\mathrm{s})$ of the dike material and compared to a user-specified critical shear stress $\left(\tau_{c}\right)$. Next, following the Engelund and Hansen formulation for sediment transport, lowering of the breach level is computed for which a porosity of the dike material is needed. In addition, lateral breach growth is related to the vertical growth by the so-called Side Erosion Index (SEI)

\subsection{Breaching module in IWRS (HR Wallingford)}

Within the HR Breach module, the discharge through the breach is calculated by applying a standard weir formula with a discharge coefficient as a function of the curvature of the invert. An combination of the energy balance equation and volume balance equation are then used to calculate the flow velocities through several grid points. Hence HR Breach is a grid based method. Headcut

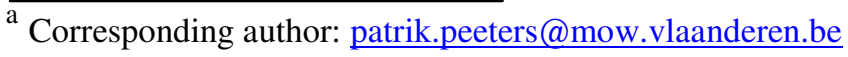


migration is accounted for through the use of the energybased formula proposed by [2]. The initial location of the cliff needs to be specified. However unlike the method proposed by [2], headcut formation is allowed to initiate at any or multiple locations along the landside slope. Several sediment transport formulae can be used to obtain the vertical breach growth. Again, lateral breach growth is related to the vertical growth through the use of an erosion Depth/Width ratio. Lateral erosion occurs over the height of the water depth, thereby undercutting the soil above. Block failures occur by means of a simplified geotechnical calculation.

\subsection{Breaching in accordance with the Verheij- van der Knaap (V-vdK) breach growth formula}

The Verheij-van der Knaap breach growth formula [3] was incorporated in a spreadsheet. The $\mathrm{V}$-vdK formula subdivides breach growth into two phases. First, vertical breach growth is calculated as a linear function of time. Therefore, the time span as well as the lowest breach level are needed as an input. Secondly, the breach will start to grow laterally provided site-specific values for $u_{c}$ as well as empirical parameters $f_{1}$ and $f_{2}$. The flow through the breach is obtained using a standard weir flow formula. Drowned flow conditions are not taken into account here. It should be noted that breach growth is only function of the difference between the upstream and downstream water levels and independent of the calculated discharge.

\subsection{BRES-Visser (TU Delft) [4]}

Again, the discharge through the breach is calculated using a standard weir formula. Similar to Mike11, a dimensionless (bed) shear stress is calculated and compared to a parameter for incipient motion, i.e. a critical shear stress $\left(\tau_{c}\right)$. The latter is calculated by the code as a function a particle diameter $\mathrm{D}_{*}$ (which is in turn function of $\mathrm{D}_{50}$ ).

First, steepening and retrograde erosion of the landside slope is assumed, resp. Stages I and II. Next in Stage III, the crest height decreases and the breach width start to increase. Finally, breach growth continues in Stages IV and V. For sediment transport along the landside slope an analytical approximation of Galapatti's model is used to describe the process of sediment entrainment. For Stages I, II, III a relatively steep sloping bed and for Stages IV, $\mathrm{V}$ a milder sloping bed are assumed. Different sediment transport formulae can be chosen. For Stages III to V, (again) lateral erosion is controlled by the vertical erosion.

\subsection{AREBA (TU Delft)}

According to [5], the flow through the breach in AREBATUD follows from the weir formula with 3 variable weir coefficients depending on the stage of breach formation. During the retreat of the landside slope towards the riverside slope, the first weir coefficient is applied which represents the effects of vertical contraction. The moment the retreat of the landside slope reaches the riverside slope, the first weir coefficient is multiplied with a second weir coefficient which represents the effects of horizontal flow contraction. Once a full breach has formed the first two weir coefficients are replaced by a third weir coefficient that mainly represents the effects of horizontal contraction once a full breach has formed. Based on the discharge calculation, the shear stresses are derived at breach crest level. In the headcut erosion (which was applied in this study) mode the downwards erosion of the crest is assumed negligible compared to the headcut progression rate and therefore has been ignored in the model. The breach widening rate is supposed to be linearly dependent on the rate at which the invert level lowers. The cross-sectional shape of the breach is thereby assumed to be rectangular. The headcut migration rate is determined via the energy-based formula proposed by [2]. The headcut coefficient is set as 1800 times the erodibility coefficient.

\section{Site-specific input data}

\subsection{Dike/Breach geometry Lillo A experiment}

Table 1 and Figure 1 describe the dike and breach geometry, i.e. pilot channel of initial gully as well as the way they are schematised within the applied breach models. Table 2 provides you with values for various soil and strength parameters needed as an input by the breach models.

\begin{tabular}{|l|l|}
\hline Dike crest level & $\sim 7.5 \mathrm{~m} \mathrm{TAW}^{(\mathrm{a})}$ \\
\hline Foundation level & $2.9 \mathrm{~m} \mathrm{TAW}$ \\
\hline Dike crest width & $\sim 5.0 \mathrm{~m}$ \\
\hline Landside slope & $\sim 3: 2\left(56^{\circ}\right)$ \\
\hline Riverside slope & $\sim 3: 2\left(56^{\circ}\right)$ \\
\hline \hline Initial breach level & $\sim 4.5 \mathrm{~m} \mathrm{TAW}$ \\
\hline $\begin{array}{l}\text { Initial breach width at } 4.5 \mathrm{~m} \\
\text { TAW }\end{array}$ & $\sim 1.0 \mathrm{~m}$ \\
\hline $\begin{array}{l}\text { Initial breach width at } 6.0 \mathrm{~m} \\
\text { TAW }\end{array}$ & $\sim 2.5 \mathrm{~m}^{(\mathrm{b})}$ \\
\hline $\begin{array}{l}\text { Initial breach width at } 7.5 \mathrm{~m} \\
\text { TAW }\end{array}$ & $\sim 8.0 \mathrm{~m}$ \\
\hline Initial breach side slope & $\sim 2: 1\left(63^{\circ}\right)^{(\mathrm{b})}$ \\
\hline $\begin{array}{l}\text { Initial breach length at } 4.5 \mathrm{~m} \\
\text { TAW }\end{array}$ & $\left.\sim 8 \mathrm{~m}{ }^{(\mathrm{c})}\right)$ \\
\hline $\begin{array}{l}\text { Initial breach length at } 6.0 \mathrm{~m} \\
\text { TAW }\end{array}$ & $\sim 7.0 \mathrm{~m}$ \\
\hline Final breach width ${ }^{(\mathrm{d})}$ & $\sim 20.0 \mathrm{~m}$ \\
\hline \hline Polder level & $4.0 \mathrm{~m} \mathrm{TAW}$ \\
\hline Polder Area & $13 \mathrm{ha}$ \\
\hline
\end{tabular}



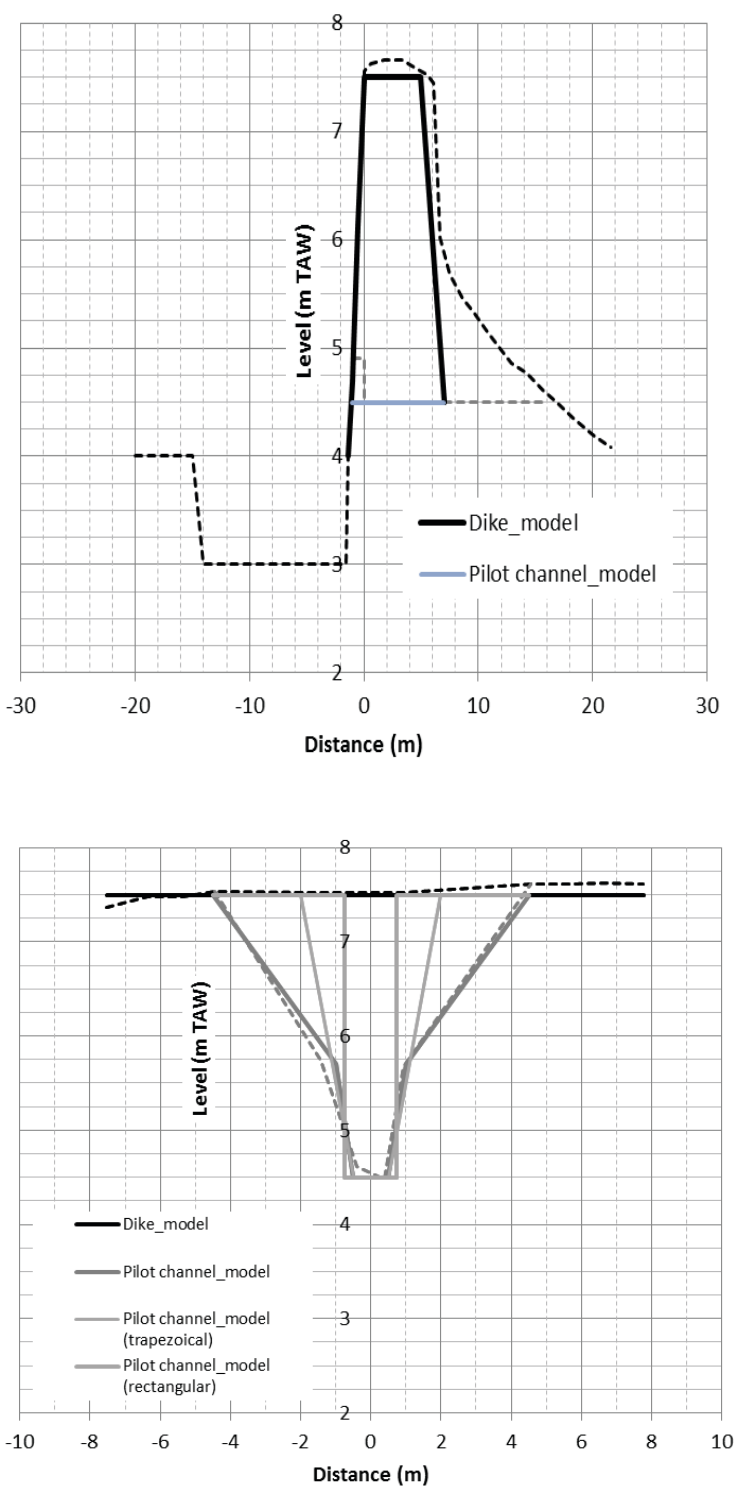

Figure 1. Schematisation of the breach section: cross-section (top, distance 0 at Transect 0 ) and longitudinal section at Transect 5 (bottom, view from Lillo A towards the river Scheldt) (Dashed lines correspond to the actual field situations)

\subsection{Dike material characteristics}

Within the different breach models the dike material needs to be characterised. The list of input parameters and their values are shown in Table 2.

\section{Results and discussion}

\subsection{Headcut migration}

From Figure 2 it can be seen that HR Breach and AREBA-TUD succeed pretty well in reproducing the upstream headcut migration. Understandable, the retrograde erosion simulated by BRES-Visser arrives too quickly (easy) at the riverside.

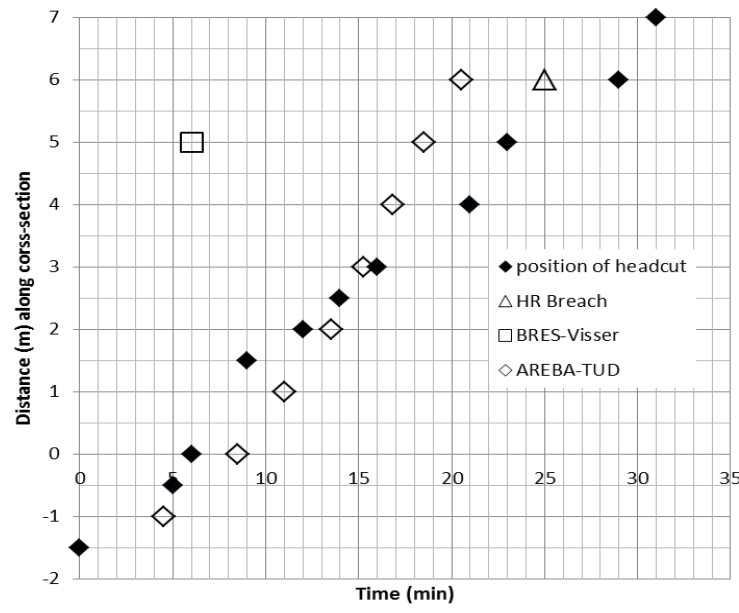

Figure 2. Position of the headcut

\subsection{Vertical and lateral breach growth}

The outcomes for vertical breach growth are shown in Figure 3. Figure 4 shows the breach growth in width.

MIKE and HR Breach allow vertical and lateral breach growth to occur in parallel, where V-vdK, BRES-Visser and AREBA-TUD follow a more sequential approach. It should be noted that $\mathrm{vdK}$ is forced to reached the final breach level of 3,2 m TAW in 22 minutes, being the time after which breach growth in width started in the field experiment.

In accordance with the short time needed for retrograde erosion, vertical growth simulated by BRES-Visser is taking place quite early. Following the results for the headcut migration with both HR Breach and AREBA, here the start of the vertical breach growth is well predicted. By all three models, the vertical erosion occurs rather rapid. Finally, MIKE is somewhat slower as compared to the other models. The final breach levels obtained with the applied models are satisfying.

Regarding breach growth in width, the results obtained with $\mathrm{V}$-vdK are incredibly well fitting the field data. HR Breach needed to be forced to stop at $20 \mathrm{~m}$. on the other hand, MIKE, BRES-Visser and AREBA-TUD are underestimating the final breach width.

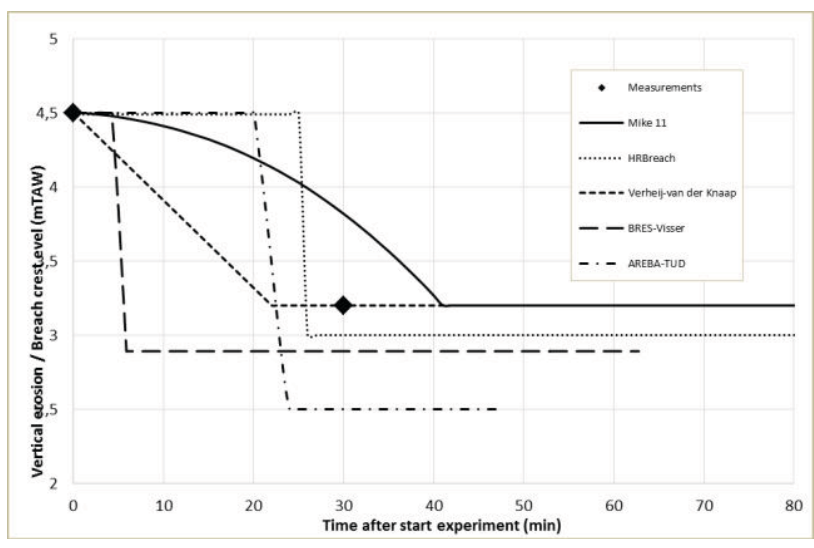

Figure 3. Breach crest level 
FLOODrisk 2016 - $3^{\text {rd }}$ European Conference on Flood Risk Management

\begin{tabular}{|c|c|c|c|c|c|}
\hline & $\begin{array}{l}\text { Mike11 } \\
\text { (Marcelo) }\end{array}$ & HR Breach & V-vdK & $\begin{array}{l}\text { BRES- } \\
\text { Visser }\end{array}$ & $\begin{array}{l}\text { AREBA- } \\
\text { TUD }\end{array}$ \\
\hline Dry Unit Weight $\left(\mathrm{kN} / \mathrm{m}^{2}\right)$ & & 17.0 & & & \\
\hline $\begin{array}{l}\text { Specific Gravity/ } \\
\text { Sediment Density }\left(\mathrm{kg} / \mathrm{m}^{3}\right)\end{array}$ & 2.65 & & & 2.65 & \\
\hline $\mathrm{D}_{10}(\mathrm{~mm})$ & & & & 0.002 & \\
\hline $\mathrm{D}_{50}(\mathrm{~mm})$ & 0.04 & 0.04 & & $0.054^{*}$ & \\
\hline $\mathrm{D}_{90}(\mathrm{~mm})$ & & & & 0.13 & \\
\hline Porosity (\%) & 35 & 35 & & 35 & \\
\hline Friction Angle/Angle of repose $\left(^{\circ}\right)$ & & 22 & & 22 & 22 \\
\hline Cohesion $\left(\mathrm{kN} / \mathrm{m}^{2}\right)$ & & 2.0 & & & 2.0 \\
\hline Ip & & 31 & & & \\
\hline Erodibility Coefficient $\left(\mathrm{cm}^{3} / \mathrm{N} \cdot \mathrm{s}\right)$ & & 1 & & & 5 \\
\hline Headcut migration coefficient & & $\begin{array}{c}0.005- \\
0.015-0.2\end{array}$ & & & 0.009 \\
\hline Mannings' $\mathrm{n}$ & & $\mathbf{0 . 0 3}$ & & & $\mathbf{0 . 0 3}$ \\
\hline $\mathrm{u}_{\mathrm{c}}(\mathrm{m} / \mathrm{s})$ & & & $\begin{array}{l}0.1-0.225- \\
10.0\end{array}$ & & \\
\hline$\tau_{\mathrm{c}}\left(\mathrm{N} / \mathrm{m}^{2}\right)$ & 0.2 & 0.2 & & $\begin{array}{l}\text { I-II-III: } \\
\text { Bagnold- }\end{array}$ & 0.2 \\
\hline Sediment transport & $\begin{array}{c}\text { Engelund- } \\
\text { Hansen }\end{array}$ & Hanson & & $\begin{array}{l}\text { IV-V: Van } \\
\text { Rijn }\end{array}$ & Temple \\
\hline $\mathrm{SEI}^{-1} / \mathrm{DW}$ ratio & $\begin{array}{l}1.3-0.5- \\
0.125\end{array}$ & 0.75 & & f(III,IV,V) & 1.6 \\
\hline $\mathrm{f}_{1}$ & & & $0.5-1.3-5.0$ & & \\
\hline$f_{2}$ & & & $\begin{array}{l}0.01-0.04- \\
1.0\end{array}$ & & \\
\hline $\begin{array}{l}\text { Time of vertical breach growth } \\
\text { (min) }\end{array}$ & & & 22 & & \\
\hline Friction coefficient $-\mathrm{C}_{\mathrm{f}}$ & & & & 0.025 & \\
\hline
\end{tabular}

Table 2. Properties of the dike used as input for the breach model 


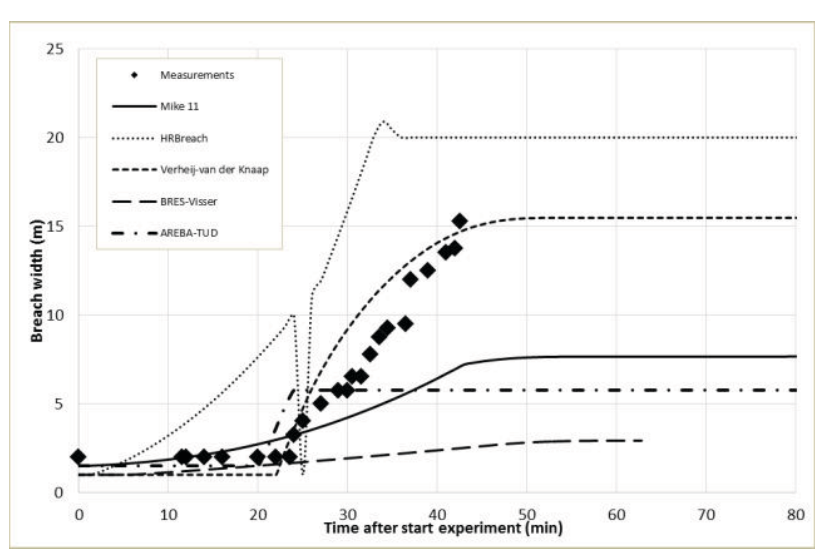

Figure 4. Breach growth in width.

\subsection{Breach flow}

Finally, by combining breach dimensions and (broadcrested) weir flow formulas (applied with standard/default discharge coefficients), the flow through the breach breach flow is obtained (Figure 5).

By forcing the vertical growth to end and the width growth to start at $22 \mathrm{~min}$, breach dimensions and hence breach flows are overestimated by $\mathrm{V}$-vdK. All other models predict peak flows within a reasonable range. However, the timing is directly related to the way vertical and lateral growth are accounted for.

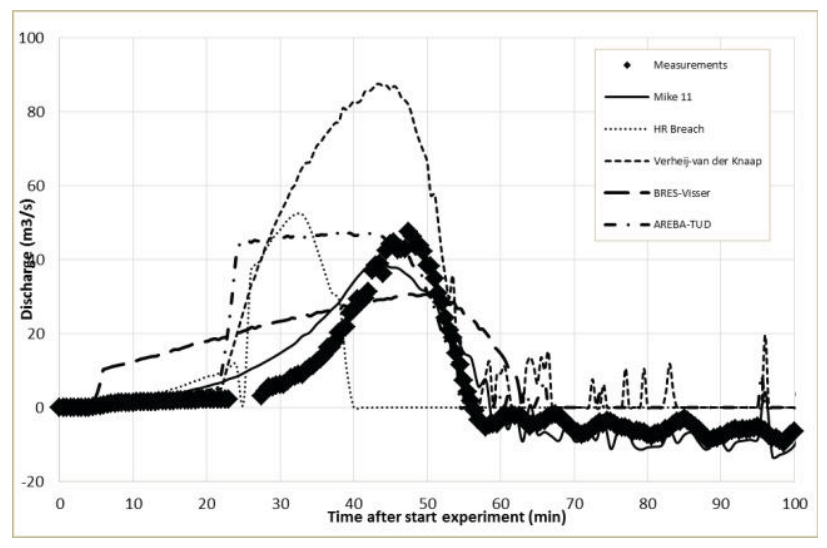

Figure 5. Breach Flow.

\section{Conclusions}

Prior to discussing the results and differences between the applied breach models, it is stressed that all breach models should be used with care as well as caution and do need specialised expertise and relevant experience. Whether certain software does not allow for negative flow conditions (HR Breach, BRES-Visser, AREBATUD), how downstream water levels are calculated (BRES-Visser) and that too large differences between dike and breach crest result in instabilities (HR Breach, AREBA-TUD), if a discharge coefficient as a function of the curvature of the invert is taking into account (HR Breach) can hardly be derived when reading manuals only.
The good news is that most/all models provide useful results starting from the same input regarding the strength parameters. In some cases (HR Breach, V-vdK) foreknowledge comes in handy or is even needed.

It should be clear that although there is a tendency towards a general consensus for the (whole) breaching process, the sequential approach is not hard coded in every breach model.

Except for $\mathrm{V}$-vdK, lateral growth is directly related to the vertical growth.

Only AREBA-TUD and HR Breach take a varying discharge coefficient into account in order to account for the occurende of so-called converging flow.

Taking into account retrograde erosion/headcut migration has an important influence on the timing of the peak flow through the breach.

Finally, it is recommend not to use terms like inner and outer slope, but rather river- and landside or core and top layer.

\section{References}

1. Peeters, P.; Zhao, G.; de Vos, L.; Visser, P.J. (2014). Large-scale dike breaching experiments at Lillo in Belgium, in: Cheng, L. et al. (Ed.) (2015). Proceedings of the 7 th International Conference on Scour and Erosion - ICSE 2014, The University of Western Australia, Perth, Australia, 2-4 December 2014. pp. 289-297.

2. Temple, D.M., Hanson, G.J., Neilsen, M.L. and Cook, K.R. (2005). 'Simplified breach analysis model for homogeneous embankments: Part 1, Background and model components', 25th Annual USSD Conference, Salt Lake City, Utah, USA, 610 June 2005.

3. Verheij H. J. (2003). Aanpassen van het bresgroeimodel in HIS-OM, Technische Rapport Q3299, Delft Hydraulics, Delft.

4. Visser P.J. (1998). Breach growth in sand-dikes, PhD. Thesis, Delft University of Technology, Delft.

5. M. Van Damme. (2015). Rapid embankment breach modelling with AREBA. 